\title{
Neurotoxicological Effects of Municipal Effluents in Fathead Minnow Pimephale Promelas
}

\author{
Gagné, F., Trépanier, S., André, C. \\ Aquatic Contaminants Research Division, Environment and Climate Change Canada, 105 McGill, Montreal, QC, \\ Canada H2Y 2E7 \\ Email: francois.gagne@canada.ca
}

\begin{abstract}
Municipal effluents are known to be able of disrupting neuro-endocrine signaling pathways in oviparous organisms. The purpose of this study was to examine the neurotoxicity of a chemically-treated municipal effluent to adult fathead minnow (Pimephales promelas) after 21 days. Brain somatic index and lipid peroxidation (LPO), monoamine oxidase (MAO) and acetylcholinesterase (AChE) levels were determined in both male and female fish. The estrogenicity of the municipal effluent was confirmed by measuring vitellogenin production and energy expenses in the liver. Brain MAO and AChE activities increased at low effluent concentrations and decreased at higher concentrations $(>10 \% \mathrm{v} / \mathrm{v})$. The data suggest that males expend more metabolic energy than females and was related to vitellogenin, and that brain activity is impaired in both sexes in the presence of the effluent. In conclusion, exposure to municipal effluents could produce biochemical changes in the central nervous system in fish.
\end{abstract}

Keywords: Fathead minnow, municipal effluents, acetylcholinesterase, monoamine oxidase activity, oxidative stress.

\section{$1 \quad$ Introduction}

Municipal effluents are known to be major sources of contamination in aquatic ecosystems [1]. Indeed, they release a complex cocktail of contaminants, including metals, polyaromatic, polycyclic and halogenated hydrocarbons, as well as endocrine-disrupting substances, such as estrogenic and serotonergic compounds, to the environment $[2,3]$. Municipal effluents were found to feminize fish [4] mussels [5] and induce spawning in mussels [6]. Exposure to municipal effluents is well recognized to induce the synthesis of the egg yolk protein precursor vitellogenin (VTG), which is under the control of the estrogen receptor [7]. The production of VTG is highly energy demanding since it is a glycolipophosphoprotein which serves as the main source of food energy in developing embryos. It is synthetized in the liver and travels to the oocytes via the plasma. Exposure of fathead minnow (Pimephales promelas) to municipal effluents resulted in increased plasma VTG and ovipositor development in males. This could pose a health risk in males, since there is no means of eliminating this protein, which can cause damage to kidneys [8]. The reported hormonal effects (estrogenicity and serotonergicity) of municipal effluents have raised concerns on the possible neuronal impacts of these complex mixtures. Indeed, animal studies revealed that endocrine disruptors could also influence various behaviors such as rearing, locomotion, anxiety in mothers and learning/memory disorders in offspring [9]. The occurrence of pharmaceutical products that are found at concentrations between $\mathrm{ng} / \mathrm{L} \mathrm{to} \mu \mathrm{g} / \mathrm{L}$ in wastewater effluents could also impact the neurophysiological status in fish and other vertebrates. In another study, Danio rerio larvae exposed to environmentally relevant concentrations of propranolol, a $\beta$-blocker for the treatment of hypertension, had reduced testosterone and estradiol-17 $\beta$ and showed a more passive behavior compared to control larvae [10].

This raises the question that exposure to municipal effluent could also impede at the neurological level in fish as well. This was previously shown in freshwater mussels exposed to municipal effluents [11]. Mussels exposed to a primary-treated effluent had elevated levels dopamine and acetylcholinesterase activity in the visceral ganglia and the latter was significantly related to vitellogenin-like proteins (a marker of estrogenicity). These studies suggest that municipal effluents and pharmaceutical products 
could have detrimental effects on central monoaminergic neurons, such as dopamine and serotonin. However, the neurological consequences of exposure to municipal effluents are not well understood in aquatic organisms at the present time. In a previous study, carps (Cyprinus carpio) exposed to municipal effluents exhibited a reduced gonado-somatic index and increased plasma vitellogenin (VTG). Steroids (estradiol-17 $\beta$ and testosterone) found in the effluents were bioavailable to fish with a bioconcentration factor of approximately 32 after 141 days of exposure [12]. Exposure to a hospital effluent led to elevated levels of lipid peroxidation (LPO) not only in the usual tissues such as the gills and liver but in brain of exposed carps, suggesting that pharmaceutical-rich waste waters induces oxidative stress in fish [13]. In another study, evidence of oxidative stress and damage was observed in rainbow trout (Oncorhynchus mykiss) exposed to secondary and tertiary-treated municipal effluents [14]. Mitochondria electron transport activity represents one of the major sources of reactive oxygen species in cells [15]. Moreover, some pharmaceuticals found in municipal effluents increased metabolic energy expenditure at the cellular level in the visceral tissues of mussels thereby contributing to the production of reactive oxygen species in cells [16].

Few studies are available on the effects of municipal effluents on brain or neural activity in aquatic organisms, especially fish. Brain activity can be characterized by measuring changes in acetylcholinesterase (AChE) and monoaminergic activity by following changes in monoamine oxidase activity (MAO) in the brain. In a recent study, Astyanax sp. and zebrafish (Danio rerio) exposed to municipal and agricultural effluents exhibited reduced AChE activity in muscle and increased metallothionein (MT) gene and heat shock protein 70 expression in brain tissues [17]. This suggests that the brain could also be impacted in fish exposed to municipal effluents. Altered MAO activity in fish exposed to municipal effluents has yet to be examined in organisms exposed to effluents containing high levels of neuroactive pharmaceutical products [18]. In a previous study, increased MAO activity and reduced serotonin levels were observed in mussels exposed to municipal effluents, which suggests that the effluents could alter biogenic amine (dopamine, adrenaline and serotonin) metabolism in aquatic organisms [19].

The purpose of this study was therefore to examine the neurotoxicity of chemically-treated municipal effluents in the central nervous system of adult fathead minnows. Neurotoxicity was determined by measuring brain LPO, MAO and AChE activities. These responses were examined in respect to energy expenditure (MET) and estrogenicity (VTG) in adult fathead minnow exposed to a municipal effluent.

\section{Methods}

\subsection{Fathead minnow reproduction assay and exposure to municipal effluent}

Fish were cultured and bred at a fathead minnow colony at the wet laboratory of the aquatic toxicology laboratory at the Montreal wastewater treatment plant (QC, Canada). The municipal wastewater treatment consisted of removal of large (sedimentation) and flocculation of small solids by the use of grids and surfactants. The study employed a 21-day continuous exposure regime with a 2:1 female to male ratio in $12.5 \mathrm{~L}$ tanks that continuously received diluted municipal effluents $(1 \mathrm{~L}$ per hour and preheated at $25 \mathrm{oC}$ ). Two male and four female fish were held in a $12.5 \mathrm{~L}$ aquariums for 7 days prior to exposure to the effluent and three tanks per treatment groups were prepared making a total replication of 12 females and 6 males. Only actively reproducing adults (males protecting tiles and females actively laying eggs to tiles) were selected for the exposure study. Exposure to the effluent was initiated with concentrations of 5,10 and $20 \% \mathrm{v} / \mathrm{v}$ at $25 \mathrm{oC}$. The fish were fed daily with commercial feed during the exposure experiments (10 g per aquarium). Control fish were exposed to charcoal-filtered and UVtreated tap water from the City of Montreal. The fish were exposed for 21 days under constant aeration and a 16h-light/8h-dark photoperiod. Water $\mathrm{pH}$, conductivity, redox potential, ammonia, nitrates, turbidity, dissolved oxygen and temperature were monitored daily. The spawning tiles were checked for egg production (the tiles were replaced with new ones each day) and fertilization success. At the end of the exposure period, the fish were anesthetized in tricaine methanesulfonate (MS-222 at $50 \mathrm{mg} / \mathrm{L}$ dissolved in aquarium water and $10 \mathrm{mM}$ NaHCO3 at pH 7.5, Sigma-Aldrich, Ontario, Canada) in accordance with the recommendations of the animal care committee. Fork length and wet body, gonad, 
gill, brain and liver weights were recorded. The male conf111and female secondary sexual characteristics were assessed: ovipositor, banding coloration in males, nuptial tubercles and head-sponge appearance. The organs were then mixed in 3 volumes of homogenization buffer before freezing at -85 oC. The homogenization buffer was composed of $250 \mathrm{mM}$ sucrose, $25 \mathrm{mM}$ Hepes-NaOH, pH 7.4, containing $1 \mathrm{mM}$ dithiothreitol and $10 \mathrm{\mu g} / \mathrm{ml}$ aprotinin (protease inhibitor), and the tissues were homogenized using a Teflon pestle tissue grinder ( 5 passes) on ice. A portion of the homogenate was centrifuged first at 3000 $\mathrm{x} \mathrm{g}$ for $15 \mathrm{~min}$ at $4 \mathrm{oC}$, and the resulting supernatant (S3 fraction) was centrifuged at $15000 \mathrm{x} \mathrm{g}$ for 30 min at $4 \mathrm{oC}$. The supernatant (S15 fraction), S3 fraction and homogenate were then conserved at $-85 \mathrm{oC}$ until analysis.

\section{$2.2 \quad$ Neuorotoxicity assessment}

Acetylcholinesterase (AChE) activity was determined using the acetylthiocholine substrate assay [20]. The assay was performed using $3000 \mathrm{x}$ g supernatant of brain homogenate in the presence of $0.5 \mathrm{mM}$ acetylthiocholine and Ellman's reagent (5,5'-dithiobis(2-nitrobenzoic acid) at pH 7.2 in $100 \mathrm{mM}$ Trisacetate buffer. The formation of thiocholine in time (0-30 min at $30 \mathrm{oC})$ was followed by absorbance at $412 \mathrm{~nm}$ in clear polystryrene microplates (Synergy 4, Biotek Instruments, USA). A calibration curve was prepared using reduced glutathione, and the data were expressed as $\mu \mathrm{mol}$ thiols $/ \mathrm{min} / \mathrm{mg}$ protein in the S3 fraction. Monoamine oxidase (MAO) activity was determined by the coupled dichlorofluoresceinperoxidase activity as described elsewhere [3]. The mitochondria were first isolated by centrifugation of the S3 fraction at $9000 \mathrm{x} \mathrm{g}$ for $20 \mathrm{~min}$ at $4 \mathrm{oC}$, the mitochondrial pellet was resuspended in the homogenization buffer and referred to as the crude mitochondrial fraction. The reaction mixture consisted of $100 \mu \mathrm{M}$ tryptamine, $2 \mu \mathrm{M}$ dichlorofluorescein, $100 \mu \mathrm{M}$ aminotriazole (a catalase inhibitor) and $1 \mathrm{\mu g} / \mathrm{mL}$ horseradish peroxidase. The reaction was started by the addition of $50-100 \mu \mathrm{g} / \mathrm{mL}$ total protein of the mitochondrial fraction and incubated at $30 \mathrm{oC}$ for $0,10,20$ and $30 \mathrm{~min}$. Fluorescence readings were taken at $485 \mathrm{~nm}$ excitation and $520 \mathrm{~nm}$ emission at each time. Enzymatic activity was expressed as the increase in fluorescence/min/mg protein. Standard solutions of fluorescein were used for optimal instrument adjustments at these wavelengths and calibration. Total proteins in these fractions were determined using the Coomassie Blue dye binding assays [21]. Standard solutions of bovine serum albumin were used for calibration.

\section{$2.3 \quad$ Oxidative stress assessment}

Lipid peroxidation (LPO) was determined in brain homogenates using the thiobarbituric acid method [22]. A volume of $50 \mu \mathrm{L}$ of the homogenate was mixed with $200 \mu \mathrm{L}$ of $10 \%$ trichloroacetic acid containing $1 \mathrm{mM} \mathrm{FeSO} 4$ and $100 \mu \mathrm{L}$ of $0.7 \%$ thiobarbituric acid and heated at $70-80 \mathrm{oC}$ for $10 \mathrm{~min}$. The mixture was cooled to room temperature and centrifuged at $10000 \mathrm{x} \mathrm{g}$ for $5 \mathrm{~min}$ to remove any precipitates. A $200 \mu \mathrm{l}$ volume was transferred to a 96 -well dark microplate, and fluorescence readings were taken at $520 \mathrm{~nm}$ excitation and $600 \mathrm{~nm}$ emission. Standard solutions of tetrametoxypropane (stabilized form of malonaldehyde) were prepared for calibration on the blank (homogenization buffer). Results were expressed as umole thiobarbituric acid reactants (TBARS)/mg total proteins in the homogenate.

\subsection{Vitellogenin production and energy expenditure in the liver}

The livers were removed from the fish and rinsed in sucrose homogenization buffer at 4oC to remove excess blood. They were then homogenized using a Teflon pestle tissue grinder (5 passes at 4 oC) and centrifuged at $1500 \mathrm{~g}$ for $10 \mathrm{~min}$ at $4 \mathrm{oC}$. The supernatant was centrifuged again at $10000 \mathrm{x} \mathrm{g}$ for 20 min at $4 \mathrm{oC}$. The supernatant (S10 fraction for vitellogenin assessment) was carefully removed from the pellet (mitochondria). Vitellogenin (VTG) levels in fathead minnow were determined using a commercial immunoassay for VTG (Biosense, Cayman Chemicals, USA). The assay is based on the competitive binding of standard VTG to fixed antibodies in the presence of dilutions of the S10 fraction. The data were expressed as ng VTG/mg proteins in the S10 fraction of liver homogenates. Mitochondrial electron transport activity was determined in the mitochondrial fraction (resuspended in $0.5 \mathrm{~mL}$ of homogenization buffer) using a dye reduction method as previously described [23]. The assay is based on 
the reduction of a tetrazolium dye which was significantly associated with cellular respiration rates (CO2 production) in miscellaneous organisms [24]. First, the crude mitochondrial fraction was obtained by centrifuging the $\mathrm{S} 3$ fraction at $9000 \mathrm{x}$ g for $20 \mathrm{~min}$ at $4 \mathrm{oC}$. The pellet was resuspended in $0.1 \mathrm{M}$ Tris- $\mathrm{HCl}$, pH 8.5, containing $0.1 \mathrm{mM} \mathrm{MgSO} 4,0.1 \%$ Triton X-100 and 5\% polyvinylpyrrolidone and resuspended by pipette aspiration; $1 \mathrm{mM}$ of NADH and $0.2 \mathrm{mM}$ NAPDH were then added to the mitochondrial suspension. The reaction was started by adding $1 \mathrm{mM}$ of p-iodonitrotetrazolium. The reaction was allowed to proceed at $20 \mathrm{oC}$ for $30 \mathrm{~min}$ and absorbance readings were taken at $520 \mathrm{~nm}$ at 5 -min intervals. The data were expressed as absorbance increase $/ 30 \mathrm{~min} / \mathrm{mg}$ mitochondrial protein content.

\subsection{Data analysis}

The exposure experiment consisted of 2 males and 4 females per treatment aquarium and 3 aquariums per treatment were used. Tissue biomarkers were analyzed in $\mathrm{N}=6$ males and $\mathrm{N}=12$ females fish using two-way factorial analysis of variance (exposure concentrations and sex as the main factors) after verifying for homogeneity of variance and normality using the Levene's test and the Shapiro-Wilk test, respectively. In some case, analysis of covariance was also used to determine the contribution of other biomarkers to the observed changes with effluent concentration or gender. Correlation analysis was also performed using the Pearson product-moment correlation. To determine the major physiological changes induced by exposure to municipal effluents, a discriminant function analysis and factorial analysis were performed. All statistical tests were performed using Statistica software (version 8). Significance was set at $\alpha=0.05$.

\section{Result}

The basic chemical parameters of the diluted municipal effluent (Table 1) were determined to determine changes during the 21-day exposure period. The chemical parameters were found to be constant in time. All chemical parameters changed with effluent concentration. Water conductivity, un-ionized and ionized ammonia increased significantly with exposure concentration. Water $\mathrm{pH}$, redox potential and $\mathrm{O} 2$ saturation were significantly lower at the highest effluent concentration (20\%). Dissolved ammonia concentrations were below the toxic threshold (approximately $17.6 \mathrm{mg} / \mathrm{l}$ total ammonia) at $0.029 \mathrm{mg} / \mathrm{L}$ and $0.85 \mathrm{mg} / \mathrm{L}$ for un-ionized and total ammonia, respectively. Total dissolved oxygen decreased from $110 \%$ saturation in the control tanks to $94 \%$ saturation $(7.62 \mathrm{mg} / \mathrm{L})$ at $20 \%$ effluent, but conditions were not considered hypoxic.

Table 1. Physico-chemical properties of the municipal effluent.

\begin{tabular}{ccccccccc}
\hline $\begin{array}{c}\text { Effluent } \\
\begin{array}{c}\text { concentration } \\
(\% \mathrm{v} / \mathrm{v})\end{array}\end{array}$ & $\begin{array}{c}\text { Temperature } \\
\left({ }^{\circ} \mathrm{C}\right)\end{array}$ & $\begin{array}{c}\text { Conductivity } \\
(\mathrm{us} / \mathrm{cm})\end{array}$ & $\mathrm{pH}$ & $\begin{array}{c}\text { Redox } \\
\text { potential } \\
(\mathrm{mv})\end{array}$ & $\begin{array}{c}\mathrm{NH}_{4} \\
\mathrm{mg} / \mathrm{L}\end{array}$ & $\begin{array}{c}\mathrm{NH}_{3} \\
\mathrm{mg} / \mathrm{L}\end{array}$ & $\begin{array}{c}\mathrm{NO}_{3} \\
\mathrm{mg} / \mathrm{L}\end{array}$ & $\begin{array}{c}\text { Dissolved } \\
\text { oxygen } \\
(\mathrm{mg} / \mathrm{L})\end{array}$ \\
\hline 0 & $24.9 \pm 0.05$ & $307 \pm 0.5$ & $8 \pm 0.1$ & $143 \pm 5$ & $0.19 \pm 0.01$ & $0.11 \pm 0.005$ & $0.66 \pm 0.02$ & $9.1 \pm 0.5$ \\
5 & $24.5 \pm 0.05$ & $311 \pm 1$ & $7.9 \pm 0.1$ & $144 \pm 5$ & $0.25 \pm 0.02$ & $0.01 \pm 0.005$ & $0.66 \pm 0.03$ & $8.9 \pm 0.05$ \\
10 & $24.7 \pm 0.05$ & $315 \pm 1$ & $7.95 \pm 0.03$ & $138 \pm 2$ & $0.29 \pm 0.01$ & $0.014 \pm 0.001$ & $0.70 \pm 0.02$ & $8.9 \pm 0.1$ \\
20 & $24.7 \pm 0.05$ & $372 \pm 5$ & $7.74 \pm 0.07$ & $126 \pm 5$ & $0.81 \pm 0.5$ & $0.028 \pm 0.04$ & $0.76 \pm 0.02$ & $7.89 \pm 0.2$ \\
\hline
\end{tabular}

The morphological characteristics of the fish were examined and reported in Figure 1. The condition factor (fish weight/fork length) were significantly influenced by sex only (factorial ANOVA p $<0.01$ for sex and $\mathrm{p}>0.1$ for effluent concentration). In the controls, males were significantly larger than females, and increasing the effluent concentration had no significant effect (Figure 1A). Brain somatic index (BSI) was not significantly influenced by effluent concentration. However, a significant difference between male and female BSI was observed at $10 \%$ effluent, with a lower BSI in males than in females. Correlation analysis revealed that the BSI was significantly correlated with condition factor $(\mathrm{r}=-0.37$; $\mathrm{p}<0.05)$. Correlations are summarized in Table 2. Reproductive endpoints were reported in a previous study using the same fish batch [25](Gagné et al., 2015). The only observed changes in reproduction 
were decreased egg production and slight discoloration of males. No significant effects on fertilization rate were observed. Egg production was found to be negatively correlated with liver lipids and LPO in gills.
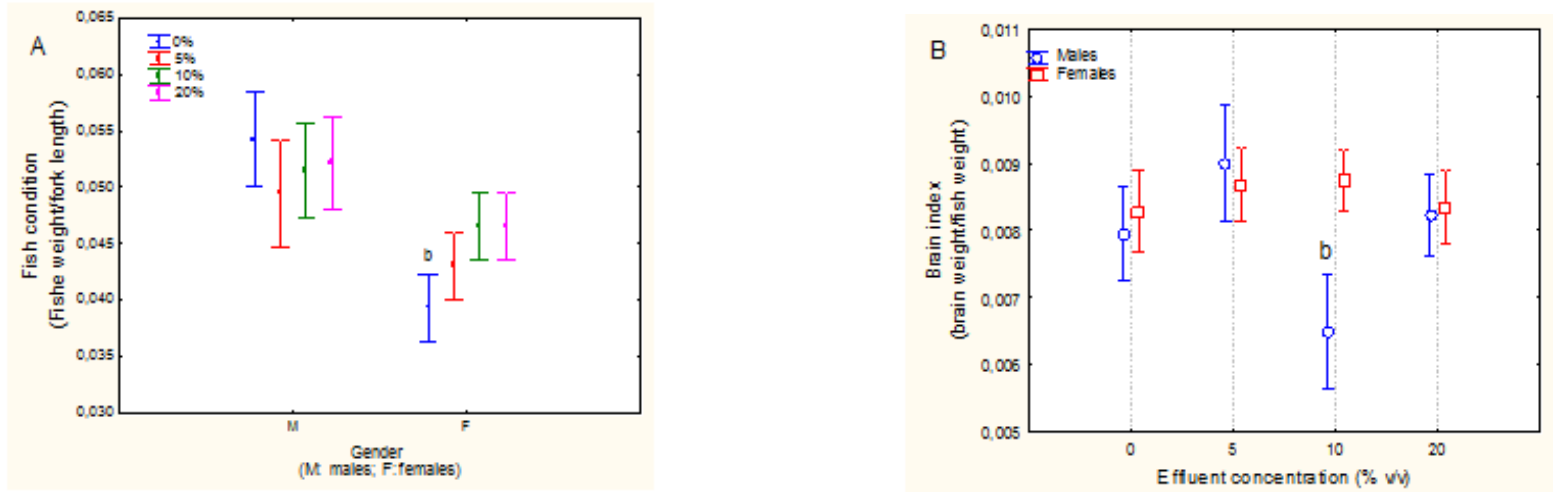

Figure 1. Fish morphological characteristics. The condition factor (fish weight/fork length) was determined in (A) and the brain somatic index or BSI were also measured in (B). The letters a and b indicate significance in the controls and between males and females at given concentrations, respectively.

Table 2. Correlation analysis of morphological and biochemical responses in fathead minnow exposed to the municipal effluent.

\begin{tabular}{|c|c|c|c|c|c|c|c|c|}
\hline & $\mathrm{CF}$ & $\begin{array}{c}\text { Brain } \\
\text { SI }\end{array}$ & $\begin{array}{l}\text { Gill } \\
\text { LPO }\end{array}$ & $\begin{array}{l}\text { Gill } \\
\text { MT }\end{array}$ & $\begin{array}{l}\text { Brain } \\
\text { LPO }\end{array}$ & AChE & VTG & $\begin{array}{c}\text { Heptic } \\
\text { MET }\end{array}$ \\
\hline $\mathrm{CF}$ & 1 & $\begin{array}{c}0.37 \\
\mathrm{p}=0.02\end{array}$ & $\begin{array}{c}0.01 \\
\mathrm{p}>0.1\end{array}$ & $\begin{array}{l}-0.24 \\
\mathrm{p}=0.1\end{array}$ & $\begin{array}{c}0.01 \\
\mathrm{p}>0.1\end{array}$ & $\begin{array}{c}0.02 \\
\mathrm{p}>0.1\end{array}$ & $\begin{array}{c}0.04 \\
\mathrm{p}>0.1\end{array}$ & $\begin{array}{c}0.30 \\
p=0.08\end{array}$ \\
\hline $\begin{array}{l}\text { Brain } \\
\text { SI }\end{array}$ & & 1 & $\begin{array}{c}-0,51 \\
p=0.005\end{array}$ & $\begin{array}{c}-0.01 \\
\mathrm{p}>0.1\end{array}$ & $\begin{array}{c}0.19 \\
\mathrm{p}>0.1\end{array}$ & $\begin{array}{c}0.34 \\
p=0.08\end{array}$ & $\begin{array}{c}0.02 \\
\mathrm{p}>0.1\end{array}$ & $\begin{array}{c}-0.06 \\
p>0.1\end{array}$ \\
\hline $\begin{array}{c}\text { Gill } \\
\text { LPO }\end{array}$ & & & 1 & $\begin{array}{c}-0.06 \\
\mathrm{p}>0.1\end{array}$ & $\begin{array}{c}0.03 \\
\mathrm{p}>0.1\end{array}$ & $\begin{array}{l}-0.04 \\
p>0.1\end{array}$ & $\begin{array}{c}0.08 \\
\mathrm{p}>0.1\end{array}$ & $\begin{array}{c}-0.01 \\
\mathrm{p}>0.1\end{array}$ \\
\hline $\begin{array}{l}\text { Gill } \\
\text { MT }\end{array}$ & & & & 1 & $\begin{array}{c}-0.21 \\
\mathrm{p}>0.1\end{array}$ & $\begin{array}{c}0.01 \\
\mathrm{p}>0.1\end{array}$ & $\begin{array}{c}0.18 \\
\mathrm{p}>0.1\end{array}$ & $\begin{array}{l}-0.30 \\
p=0.08\end{array}$ \\
\hline $\begin{array}{l}\text { Brain } \\
\text { LPO }\end{array}$ & & & & & 1 & $\begin{array}{c}0.28 \\
\mathrm{p}>0.1\end{array}$ & $\begin{array}{c}-0.61^{*} \\
\mathrm{p}=0.008\end{array}$ & $\begin{array}{l}-0.34 \\
p>0.1\end{array}$ \\
\hline $\mathrm{AChE}$ & & & & & & 1 & $\begin{array}{c}-0.44 \\
p=0.05\end{array}$ & $\begin{array}{c}-0.57 \\
p=0.009\end{array}$ \\
\hline VTG & & & & & & & 1 & $\begin{array}{c}0.53 \\
p=0.01\end{array}$ \\
\hline
\end{tabular}

*Significant correlations are highlighted in bold.

Brain neural activity was determined by measuring LPO, AChE and MAO activity (Figure 2A-C). Factorial analysis of variance of AChE activity revealed that sex had only a marginal effect $(p=0.06)$ while effluent concentration was significant at $\mathrm{p}<0.001$. AChE activity was readily suppressed by exposure to effluents, which suggests decreased neural motor activity. The decreased activity reached two-fold inhibition at $20 \%$ effluent. For brain MAO activity, factorial analysis of variance revealed that effluent concentration was significant, but not sex. MAO activity was significantly increased at $10 \%$ effluent and fell to control values at $20 \%$ effluent. For brain LPO levels, factorial analysis of variance revealed that only effluent concentration was significant and that sex had no effect. LPO was significantly lower in females at $10 \%$ effluent compared to control females. The data revealed that brain activity was lowered by exposure to the effluent. 

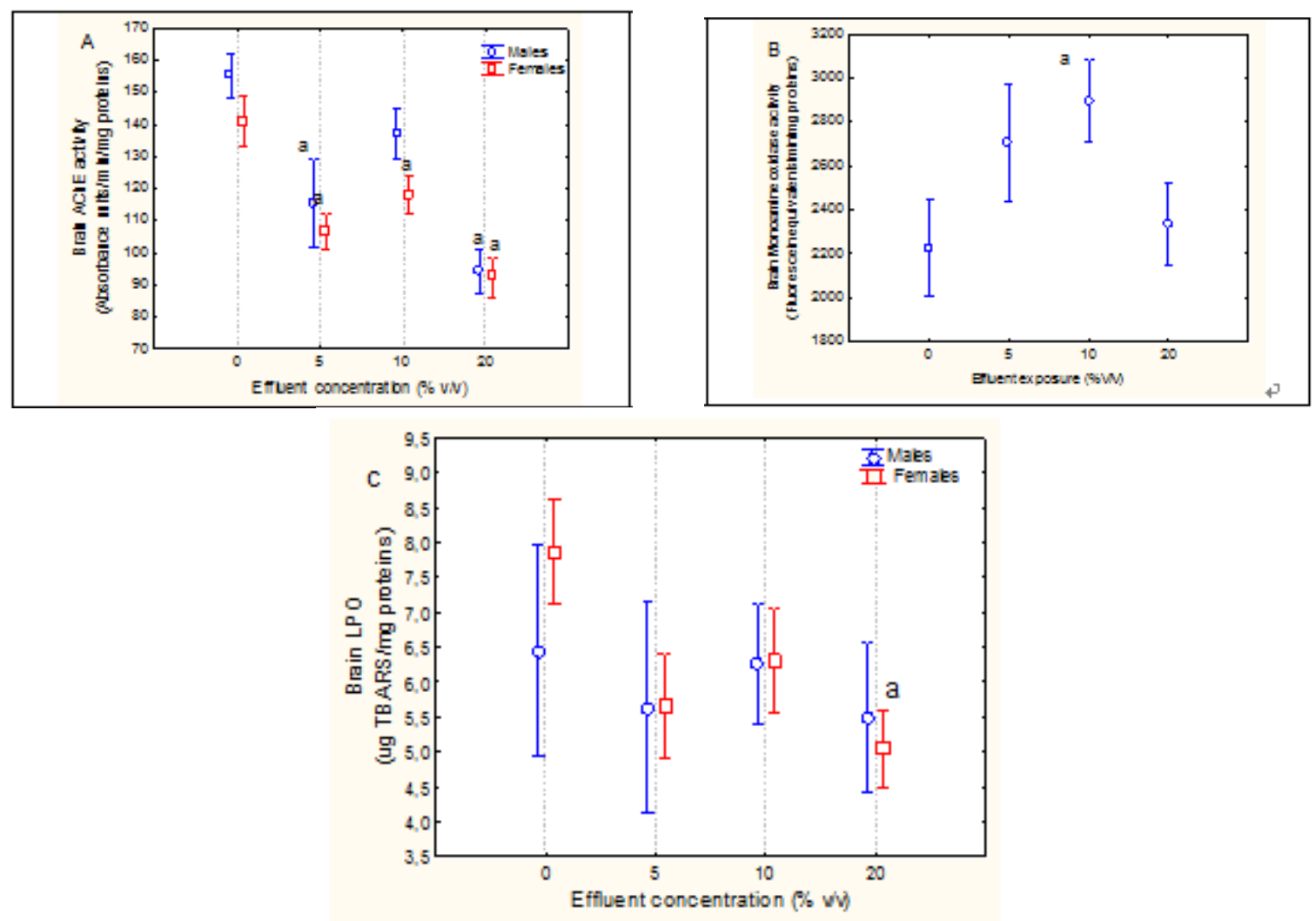

Figure 2. Neural activity and oxidative damage in the brain of effluent-exposed fathead minnow. The fish were exposed to the effluent for 21 days and analyzed for AChE (A), MAO activity (B) and LPO (c) in brain tissue. The letters $A$ and $B$ indicate significant change $(\mathrm{p}<0.05)$ between controls and sex, respectively.

Energy expenditure and vitellogenin production in the liver were also determined (Figure 3A-B). Factorial analysis of variance revealed that hepatic VTG in both males and females increased to effluent exposure (Figure 3A). VTG levels were significantly induced at $20 \%$ effluent in both males and females. Correlation analysis revealed that VTG levels were significantly correlated with brain LPO levels ( $\mathrm{r}=-$ $0.61 ; \mathrm{p}=0.004)$. Metabolic energy expenditure was monitored by mitochondrial electron transport (MET) activity (Figure 3B). The data revealed that MET activity was significantly higher at 10 and $20 \%$ concentration in males only. Correlation analysis revealed that MET activity was significantly correlated with brain AChE activity $(\mathrm{r}=-0.57 ; \mathrm{p}=0.009)$ and VTG levels $(\mathrm{r}=0.53 ; \mathrm{p}<0.05)$.
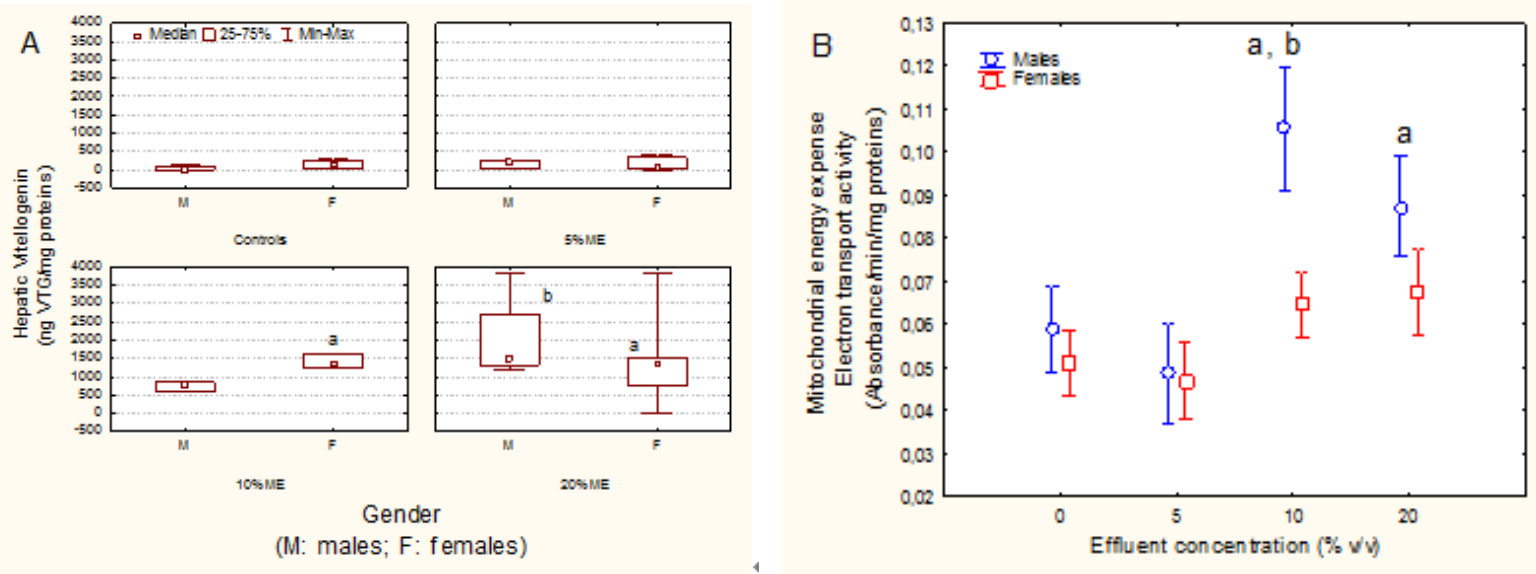

Figure 3. Hepatic vitellogenin production and energy expenditure in fish exposed to municipal effluents. The levels of VTG (A) and mitochondrial electron transport activity (B) were determined in the liver of fathead minnow 
exposed to increasing concentrations of effluent. The letters a and $b$ indicate significant difference $(\alpha=0.05)$ from the controls and between males and females, respectively.

The data were subjected to discriminant function analysis to examine the global effects of effluent exposure and to identify the most important biomarkers for concentration discrimination (Figure 4). The results revealed that biomarker responses in the controls form a distinct cluster (at $83 \%$ efficiency) from those in fish exposed to the effluent. The effluent-related effects were most noticeable at the first component ( $\mathrm{x}$ axis) where the following biomarkers had the highest factorial weights: MET, AChE, and brain LPO. On the y axis, the effluent concentrations were more discriminated at this axis where the following biomarkers explained more strongly the data (high factorial weights to the discriminant function): VTG, brain LPO and AChE in decreasing order of factorial weights. The controls and effluent concentrations were classified at 75, 75, 60 and 70\% accuracy. The last two effluent concentrations were more dispersed from the controls and $5 \%$ effluent.

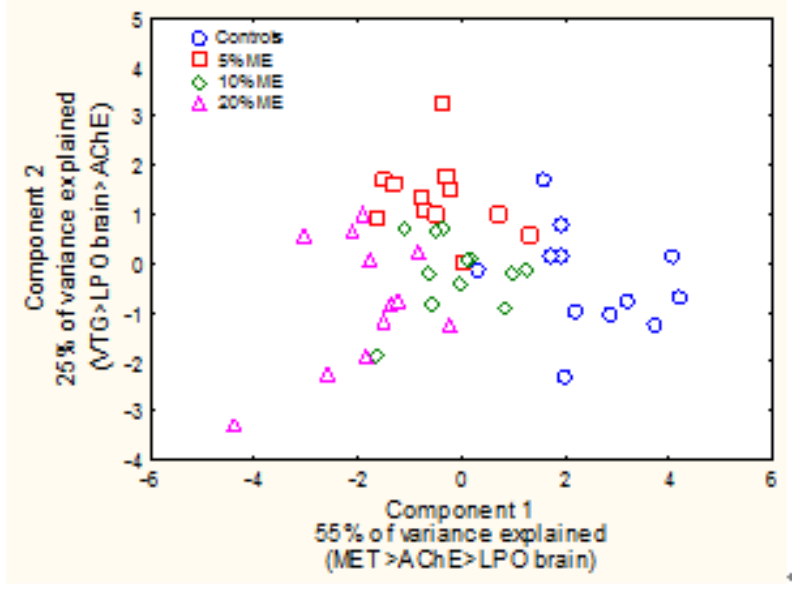

Figure 4. Discriminant function analysis. Discriminant function analysis and factor analysis were performed on the biomarker data in fathead minnow. The variance was explained at $80 \%$ by the biomarkers on each axis.

\section{Discussion}

Municipal effluents are known to contain a cocktail of contaminants, such as PAHs, halogenated hydrocarbons, metals (including metallic nanoparticles), pharmaceuticals, personal care products and steroids [26,27]. In organisms exposed to municipal effluents, a number of toxic effects are observed such as inflammation, oxidative stress, estrogenicity (vitellogenin induction and feminization) and neurological effects/behaviour [28, 29, 30]. In this study, the increase in VTG levels in the liver of exposed fathead minnow suggests the occurrence of compounds able to disrupt the estrogen signaling pathways which are commonly found in treated municipal effluents [29]. The increase in liver MET activity and significant correlation with hepatic VTG is in keeping with the mobilization of metabolic energy and lipids for the production of VTG, at least in part given the complexity of municipal effluents containing many contaminants. Moreover, an analysis of covariance for MET activity against VTG levels revealed that MET activity was still induced by the effluent, which suggests that MET activity was not only associated with VTG production which is measure of estrogenic potential. Moreover, pharmaceutical products were shown to consistently increase energy demands in mussel mitochondria [15], which can limit metabolic energy available to other physiological processes. For example, shortterm exposure of juvenile gudgeons Hypseleotris compressa to municipal effluents led to increased growth as determined by fish weight and fork length when food was not limiting [31]. Maximum swimming velocity was increased in a concentration-dependent manner, although angular velocity was reduced at high effluent concentrations (50 and 100\%). Although increased energy demands were observed in fathead minnow, no significant changes in fork length or weight were found in the present 
study. Hence, demands on energy stores for fish growth, locomotion and movement could be related to other modes of action, such as xenobiotic biotransformation, inflammation or neurotoxicity.

Endocrine disruptors could also produce impacts at the neurological level since hormone signaling is usually coupled with neurological function and behavior [32]. Exposure for example to bisphenol A and ethinyl-estradiol can disrupt sexual differentiation and adult behavior in fish suggesting that these endocrine disrupters could also lead to behavioral changes in adult and their offsprings as well. Exposure of fathead minnow to high $(44 \mathrm{ng} / \mathrm{L})$, but realistic, concentrations of estradiol-17 $\beta$ reduced competitive behaviour in males, while those exposed to low concentrations $(4 \mathrm{ng} / \mathrm{L})$ outcompeted and fathered more young than unexposed males [33]. This was also shown in a previous study where induction of vitellogenin (VTG) and reduced competitiveness was observed in fathead minnow exposed to wastewater effluents [34]. They found that gene expression signatures could not be explained solely by estrogens and androgens and that other compound were also at play. A short-term municipal effluent exposure (4-day) transcriptomic study with fathead minnow also revealed changes in cholesterol and steroid metabolism, which can, in turn, influence brain activity [35]. However, these effects are not always observed in other fish species. For example, increased mating activity was observed in male mosquitofish (Gambusia holbrooki) living in close proximity to wastewater treatment plants compared to those inhabiting a pristine site [36]. The study found that the males exposed to wastewater treatment plant effluent also spent more time interacting and associating with females.

Brain LPO levels were significantly reduced, which suggests decreased brain metabolic activity. This is consistent with decreased brain AChE activity in fish exposed to the municipal effluents albeit it was not significantly correlated with brain LPO levels. However, brain MAO activity was increased, which suggests increased catabolism of catecholamines and indolamines in the brain tissue. It is noteworthy that males and females were equally affected. The increase in MAO activity caused by exposure to municipal effluents has previously been observed in mussels [19]. Interestingly, exposure to estradiol-17 $\beta$ increased MAO activity and decreased serotonin and dopamine levels in mussels. No studies are available on the neurological effects in fish exposed to municipal effluents, but inhibition of MAO activity in fish exposed to pulp and paper mill effluents has been reported [37]. The antidepressant venlafaxine is found at low $\mu \mathrm{g} / \mathrm{L}$ concentrations in municipal effluent and was reported to cause a decrease in brain serotonin concentrations in striped bass, although MAO activity was not measured [38]. Exposure to erythromycin, a common antibiotic found in municipal effluents, led to decreased brain $\mathrm{AChE}$ activity in carp in the $\mu \mathrm{g} / \mathrm{L}$ exposure concentration range [12]. A bioconcentration factor of 72 was determined for erythromycin in fish, which suggests that this antibiotic could accumulate in fish chronically exposed to municipal effluents. The occurrence of pesticides in municipal effluent is not unlikely since pesticides are also used in urban settings [39]. One possible consequence of reduced brain $\mathrm{AChE}$ activity is reduced locomotor activity in fish exposed to the pesticide chlorpyrifos, an AChE inhibitor [39]. The authors found that a 40-55\% decrease in AChE activity was associated with decreased locomotor activity, the same range observed in the present study ( $43 \%$ decrease). If this holds true, decreased locomotor activity could form the basis of decreased male competitive behaviour when exposed to municipal effluents [40]. However, we did not quantitatively determine behavioural changes in male fathead minnow to confirm the association between brain AChE activity and locomotor activity. Further studies on this neurotoxicity-behavior interaction are warranted. In another study, pathway analysis for gene expression analysis of a $15 \mathrm{~K}$ DNA microarray indicated that genes involved in neurotransmitter secretion, general brain function and neurite growth were impaired in fish exposed to the antihypertensive drug propranolol [41]. However, these changes were not associated with any of the reproductive endpoints in fish such as fecundity, fertilization rate and hatchability, with the exception of decreased activity in males to visit the nest. Although the estrogenicity of municipal effluents was considered as possible effects at the neurological effects, municipal effluents are complex mixtures which contain other compounds such as psychoactive pharmaceuticals for example that could impede the nervous system in fish. It was recently reported that municipal effluent have anti-androgenic [42] and androgenic effects [43] which could also influence fish behavior. More research on these compounds will be required to determine impacts on the central nervous system in fish. In conclusion, exposure of fathead minnow to a chemically treated effluent led to increased hepatic VTG production and cellular energy expenses (MET) with decreased brain activity as evidenced by decreased LPO and AChE activity in the brain. In municipal effluent-exposed fish, males expend more metabolic energy in the liver than females. This was associated, in part, with the estrogenicity of the effluents as determined by 
VTG. These effects are consistent with the reported changes in male fish behaviour in the presence of an estrogenic municipal effluent.

In conclusion, continuous exposure (21 days) of fathead minnows to a physico-chemically treated effluent from a large city ( $>1$ million inhabitants) could lead to neurological alterations. Fish exposed as such display increased AChE activity and oxidative stress in brains. They spend also more metabolic energy as shown by MET activity. Based on multivariate analysis, the estrogenicity of the municipal effluent was involved in the observed neurological impacts. It is recommended to examine the neurotoxicity of municipal effluents in fish.

Acknowledgements. This project was funded under the St. Lawrence Action Plan of Environment Canada. The contribution of Patrick Cejka (in memoriam) of the Montreal wastewater treatment plant, who organized the fathead minnow exposure laboratory, is recognized. The technical assistance of Nicholas Siron and Joelle Auclair is also recognized.

\section{References}

1. C. Holeton, P.A. Chambers, L. Grace, "Wastewater release and its impacts on Canadian waters". Canadian Journal Fisheries and Aquatic Science, vol. 68, pp.1836-1859, 2011.

2. A. D. Vethaak, J. Lahr, M. Schrap, A. C. Belfroid, G. B. J. Rijs, A. Gerritsen, J. de Boer, A. S. Bulder, G. C. M. Grinwis, R. V. Kuiper, "An integrated assessment of estrogenic contamination and biological effects in the aquatic environment of The Netherlands". Chemosphere, vol. 59, pp. 511-524. 2005.

3. F. Gagné, "Neuroendocrine disruption". In: Biochemical Ecotoxicology-Principles and Methods. First Edition, Chapter 9, Elsevier Inc., USA. pp 145-170. 2014.

4. J. Aravindaksham, V. Paquet, M. Gregory, J. Dufresne, M. Fournier, D. J. Marcogliese, D. G. Cyr, "Consequences of Xenoestrogen Exposure on Male Reproductive Function in Spottail Shiners (Notropis hudsonius)." Toxicological Sciences, vol. 78,pp. 156-165, 2004.

5. F. Gagné, B. Bouchard, C. André, E. Farcy, M. Fournier, "Evidence of feminization in wild Elliptio complanata mussels in the receiving waters downstream of a municipal effluent outfall." Comparative Biochemistry and Physiology, Part C Toxicolology and Applied Pharmacology, vol. 153, pp. 99-106, 2010.

6. F. Gagné, M. Fournier, C. Blaise, "Serotonergic effects of municipal effluents: induced spawning activity in freshwater mussels". Fresenius Environmental Bulletin, vol. 13, pp. 1099-1103, 2004.

7. J. P. Sumpter, "Feminized responses in fish to environmental estrogens." Toxicology Letters, vol. 82/83: pp. 737$742,1995$.

8. J. Zha, Z. Wang, N. Wang, C. Ingersoll, "Histological alternation and vitellogenin induction in adult rare minnow (Gobiocypris rarus) after exposure to ethynylestradiol and nonylphenol." Chemosphere, vol. 66, 488-495, 2007.

9. Masuo Y, Ishido M 2011. Neurotoxicity of endocrine disruptors: possible involvement in brain development and neurodegeneration. Journal Toxicology and Environmental Health Part B Critical Reviews, vol. 14, pp.346-369, 2011.

10. K.M. Mitchell, T.W. Moon, "Behavioral and biochemical adjustments of the zebrafish Danio rerio exposed to the $\beta$-blocker propranolol." Comparative Biochemistry Physiology Part B Biochemical Molecular Biology, Vol. S1096-4959:00187-6, 2015.

11. F. Gagné, P. Cejka, C. André, R. Hausler, C. Blaise, "Neurotoxicological effects of a primary and ozonated treated wastewater on freshwater mussels exposed to an experimental flow-through system." Comparative Biochemistry Physiology PartC Toxicology and Applied Pharmacology, vol.146, pp. 460-470, 2007.

12. J. Liu, R. Wang, B. Huang, C. Lin, J. Zhou, X. Pan, "Biological effects and bioaccumulation of steroidal and phenolic endocrine disrupting chemicals in high-back crucian carp exposed to wastewater treatment plant effluents." Environmental Pollution, Vol. 162, pp. 325-331, 2012.

13. N. Neri-Cruz, L.M. Gómez-Oliván, M. Galar-Martínez, M. Del Socorro Romero-Figueroa, H. Islas-Flores, S. García-Medina, J.M. Jiménez-Vargas, N. San Juan-Reyes, "Oxidative stress in Cyprinus carpio induced by hospital wastewater in Mexico." Ecotoxicology, vol. 24, pp. 181-193, 2015..

14. M. Petala, L. Kokokiris, P. Samaras, A. Papadopoulos, A. Zouboulis, "Toxicological and ecotoxic impact of secondary and tertiary treated sewage effluents." Water Research, Vol. 43, pp. 5063-5074, 2009. 
15. P. Jezek and L. Hlavata, "Mitochondria in homeostasis of reactive oxygen species in cell, tissues, and organism." The International Journal Biochemistry Cellular Biology, vol. 37, pp. 2478-2503, 2005.

16. F. Gagné, C. Blaise, C. André, M. Salazar, "Effects of pharmaceutical products and municipal wastewaters on temperature-dependent mitochondrial electron transport activity in Elliptio complanata mussels." Comparative Biochemistry Physiology PartC Toxicology and Applied Pharmacology, vol. 143, pp. 388-393,2005.

17. D.G. Costa-Silva, M.E. Nunes, G.L. Wallau, I.K. Martins, A.P. Zemolin, L.C. Cruz, N.R. Rodrigues, A.R. Lopes, T. Posser, J.L. Franco, "Oxidative stress markers in fish (Astyanax sp. and Danio rerio) exposed to urban and agricultural effluents in the Brazilian Pampa biome." Environmental Science Pollution Research Internationnal, vol. 22, pp. 15526-15535, 2015.

18. A. Lajeunesse, S.A. Smyth, K. Barclay, S. Sauvé, C. Gagnon, "Distribution of antidepressant residues in wastewater and biosolids following different treatment processes by municipal wastewater treatment plants in Canada." Water Research, vol. 46, pp. 5600-5612, 2012.

19.F. Gagné, and C. Blaise, "Effects of municipal effluents on serotonin and dopamine levels in the freshwater mussel Elliptio complanata." Comparative Biochemistry Physiology PartC Toxicology and Applied Pharmacology, vol. 136, pp. 117-125, 2003.

20. S. Bonacci, I. Corsi, S. Focardi, "Cholinesterases in the Antarctic scallop Adamussium colbecki: characterization and sensitivity to pollutants." Ecotoxicology Environmental Safety, vol. 72, pp. 1481-1488, 2009.

21. M.M. Bradford, "A rapid and sensitive method for the quantification of microgram quantities of protein utilizing the principle of protein-dye binding." Analytical Biochemistry, vol. 72, pp. 248-251, 1976.

22. E.D. Wills, "Evaluation of lipid peroxidation in lipids and biological membranes." In: Snell, K., Mullock, B. (Eds.), Biochemical Toxicology: A Practical Approach. IRL Press, Washington, USA, pp. 127-150, 1987.

23. F. King and T.T. Packard, "Respiration and the activity of the respiratory electron transport system in marine zooplankton." Limnology and Oceanography, vol. 20, pp. 849-854, 1975.

24. F. Gagné, S. Trépanier, C. André, C. Gagnon, "Hepatic and reproductive toxicity of a physico-chemically treated municipal effluent." Current Topics in Toxicology, vol. 11, pp. 1-13, 2015.

25. Y. Luo, W. Guo, H.H. Ngo, L.D. Nghiem, F.I. Hai, J. Zhang, S. Liang, X.C. Wang, "A review on the occurrence of micropollutants in the aquatic environment and their fate and removal during wastewater treatment." Science of the Total Environment, vol. 473-474, pp. 619-641, 2014.

26. G. Brunetti, E. Donner, G. Laera, R. Sekine, K.G. Scheckel, M. Khaksar, K. Vasilev, G. De Mastro, E. Lombi, "Fate of zinc and silver engineered nanoparticles in sewerage networks." Water Research, vol. 77, pp. 72-84, 2015.

27. D.E. Vidal-Dorsch, R.C. Colli-Dula, S.M. Bay, D.J. Greenstein, L. Wiborg, D. Petschauer, N.D. Denslow, "Gene expression of fathead minnows (Pimephales promelas) exposed to two types of treated municipal wastewater effluents." Environmental Science and Technology, vol. 47, pp. 11268-11277, 2013.

28. K.D. Oakes, M.E. McMaster, G.J. Van Der Kraak, "Oxidative stress responses in longnose sucker (Catostomus catostomus) exposed to pulp and paper mill and municipal sewage effluents." Aquatic Toxicology, vol. 67, pp. 255-271, 2004.

29. F. Gagné, S.A. Smyth, C. André, M. Douville, M. Gélinas, K. Barclay, "Stress-related gene expression changes in rainbow trout hepatocytes exposed to various municipal wastewater treatment influents and effluents." Environmental Science Pollution Research Internationnal, vol. 20, pp 1706-1718, 2013.

30. S.D. Melvin, "Short-term exposure to municipal wastewater influences energy, growth, and swimming performance in juvenile Empire Gudgeons (Hypseleotris compressa)." Aquatic Toxicology, vol. 170, pp. 271-278, 2016.

31. R.K. Bhandari, S.L. Deem, D.K. Holliday, C.M. Jandegian, C.D. Kassotis, S.C. Nagel, D.E. Tillitt, F.S. Vom Saal, C.S. Rosenfeld, "Effects of the environmental estrogenic contaminants bisphenol A and $17 \alpha$-ethinyl estradiol on sexual development and adult behaviors in aquatic wildlife species." General and Comparative Endocrinology, vol. 214, pp. 195-219. 2015.

32. C. Lavelle and P.W. Sorensen, "Behavioral responses of adult male and female fathead minnows to a model estrogenic effluent and its effects on exposure regime and reproductive success." Aquatic Toxicology, vol. 101, pp. 521-528, 2011.

33. N. Garcia-Reyero, C.M. Lavelle, B.L. Escalon, D. Martinović, K.J. Kroll, P.W. Sorensen, N.D. Denslow, "Behavioral and genomic impacts of a wastewater effluent on the fathead minnow." Aquatic Toxicology, vol. 101, pp. 38-48, 2011. 
34. D. Martinović-Weigelt, A.C. Mehinto, G.T. Ankley, N.D. Denslow, L.B. Barber, K.E. Lee, R.J. King, H.L. Schoenfuss, A.L. Schroeder, D.L. Villeneuve, "Transcriptomic effects-based monitoring for endocrine active chemicals: assessing relative contribution of treated wastewater to downstream pollution." Environmental Science and Technology, vol. 48, pp. 2385-2394, 2014.

35. M. Saaristo, J. Myers, R. Jacques-Hamilton, M. Allinson, A. Yamamoto, G. Allinson, V. Pettigrove, B.B. Wong, "Altered reproductive behaviours in male mosquitofish living downstream from a sewage treatment plant." Aquatic Toxicology, vol. 149, pp. 58-64, 2014.

36. C.B. Milestone, R. Orrego, P.D. Scott, A. Waye, J. Kohli, B.I. O \&\#39;Connor, B. Smith, H. Engelhardt, M.R. Servos, D.L. Maclatchy, D.S. Smith, V.L. Trudeau, J.T. Arnason, T. Kovacs, T. Heid Furley, A.H. Slade, D.A. Holdway, L.M. Hewitt, "Evaluating the potential of effluents and wood feedstocks from pulp and paper mills in Brazil, Canada, and New Zealand to affect fish reproduction: chemical profiling and in vitro assessments." Environmental Science and Technology, vol. 46, pp. 1849-1858, 2012.

37. J.H. Bisesi, W. Bridges, S.J. Klaine, "Effects of the antidepressant venlafaxine on fish brain serotonin and predation behavior." Aquatic Toxicology, vol. 148, pp. 130-138, 2014.

38. N. Stamatis, D. Hela, I. Konstantinou, "Pesticide inputs from the sewage treatment plant of Agrinio to River Acheloos, western Greece: occurrence and removal." Water Science and Technology, vol. 62, pp. 1098-1105, 2010.

39. J.V. Rao, G. Begum, R. Pallela, P.K. Usman, R.N. Rao, "Changes in behavior and brain acetylcholinesterase activity in mosquito fish, Gambusia affinis in response to the sub-lethal exposure to chlorpyrifos." International Journal Environmental Research and Public Health, vol. 3-4, pp. 478-483, 2005.

40. H.L. Schoenfuss, E.T. Furlong, P.J. Phillips, T.M. Scott, D.W. Kolpin, M. Cetkovic-Cvrlje, K.E. Lesteberg, D.C. Rearick. "Complex mixtures, complex responses: Assessing pharmaceutical mixtures using field and laboratory approaches." Environmental Toxicology and Chemistry, vol. 35, pp. 953-965, 2016.

41. V. Lorenzi, A.C. Mehinto, N.D. Denslow, D. Schlenk, "Effects of exposure to the $\beta$-blocker propranolol on the reproductive behavior and gene expression of the fathead minnow, Pimephales promelas." Aquatic Toxicology, vol. 116-117, pp. 8-15, 2012.

42. M.J. Arlos, L.M. Bragg, W.J. Parker, M.R. Servos, "Distribution of selected antiandrogens and pharmaceuticals in a highly impacted watershed." Water Research, vol. 72, pp. 40-50, 2015.

43. E. Bandelj, M.R. van den Heuvel, F.D. Leusch, N. Shannon, S. Taylor, L.H McCarthy. "Determination of the androgenic potency of whole effluents using mosquitofish and trout bioassays." Aquatic Toxicology, vol. 80, pp. $237-248,2006$. 